\title{
Analisis Kesalahan Terjemahan Hadis-Hadis Kitab al-Jami' di dalam Bulughul Maram Karya Moh. Machfuddin Aladip
}

\author{
Khairul Anhar \\ Universitas Sumatera Utara \\ kh4.anhar@gmail.com \\ M. Husnan Lubis \\ Universitas Sumatera Utara \\ buyalais@hotmail.com \\ Rahimah \\ Universitas Sumatera Utara \\ rahimah94@yahoo.com
}

This study aims to reveal the translation errors that occurred in the translation of the hadiths of al-jami' in the book Bulughul Maram by Moh. Macfuddin Aladip and explained the factors that these errors occurred. There have been many studies on the translation of religious texts. This is very important to do in order to control the results of the translation and understanding of the people's religions on these religious texts. In this study, an assessment and analysis of the translation of the book Bulughul Maram Min Adillatil Ahkam by Moh. Machfuddin Aladip, in the chapter of Kitab al-jami '. In revealing the errors that occur in the translation, a comparison technique between the source language and the target language is used by paying attention to the aspects of sharf, nabw and dilalah science. From this study found fatal errors in the translation of several hadiths studied in the book Bulughul Maram Min Adillatil Ahkam by Moh. Machfuddin Aladip, in the chapter of Kitab aljami'. In addition, the errors that occur are caused by the following factors: (1) lexical improper matching, (2) adding words or phrases to more than words in the source text, (3) shifts that occur at the word level, (4) Elimination of equivalent words and phrases, (5) Identifying words in the source language.

Keywords: Bulughul Maram, incorrect translation, over-translation

\section{Abstrak}

Kajian ini bertujuan untuk mengungkap kesalahan-kesalahan terjemahan yang terjadi pada terjemahan hadis-hadis kitab al-jami' di dalam kitab Bulughul Maram karya Moh. Macfuddin Aladip serta 
menjelaskan faktor-faktor kesalahan tersebut terjadi. Pengkajian terhadap terjemahan teks-teks agama telah banyak dilakukan. Hal itu sangat penting dilakukan untuk mengontrol hasil-hasil terjemahan dan pemahaman agama masyarakat terhadap teks-teks tersebut agama tersebut. Di dalam Penelitian ini dilakukan pengkajian dan analisis terhadap hasil terjemahan kitab Bulugbul Maram Min Adillatil Abkam oleh Moh. Machfuddin Aladip, pada bab kitab al-jami'. Dalam mengungkapkan kesalahan yang terjadi pada terjemahan tersebut digunakan teknik perbandingan antara bahasa sumber dengan bahasa sasaran dengan memperhatikan aspek-aspek ilmu sharf, nahw dan ilmu dilalah. Dari kajian ini ditemukan adanya kesalahan-kesalahan yang fatal dalam hasil terjemahan beberapa hadis yang dikaji di dalam kitab Bulughul Maram Min Adillatil Abkam oleh Moh. Machfuddin Aladip, pada bab kitab al-jami'. Selain itu kesalahan-kesalahan yang terjadi disebabkan oleh faktor-faktor berikut: (1) Pemadanan yang tidak tepat secara leksikal, (2) Penambahan kata atau frasa melebihi kata pada teks sumber, (3) Pergeseran yang terjadi pada tataran kata, (4) Penghilangan padanan kata dan frasa, (5) Kesalahan mengidentifikasi kata di dalam bahasa sumber.

Kata kunci: Bulughul Maram, kesalahan penerjemahan,

\section{Pendahuluan}

Kitab Bulughul Maram telah menyebar di berbagai penjuru dunia, sangat dikenal oleh para ulama dan penuntut ilmu (khususnya ilmu syariat), selain itu kitab Bulughul Maram juga mendapatkan perhatian yang begitu besar dari para ulama dan penuntut ilmu di berbagai belahan dunia. Di Indonesia kitab ini tidak asing lagi bagi para penuntut ilmu-ilmu syariat, terlebih bagi masyarakat pesantren, sebab kitab ini merupakan salah satu kitab yang wajib dipelajari.

Al-katabi mengatakan: Kitab ini (Bulugbul Maram) adalah kitab yang penuh berkah, banyak orang dari timur dan barat mengambil manfaat darinya, banyak pula ahli ilmu yang menghapalnya luar kepala dan tidak menutup kemungkinan masih ada banyak syarah-syarah (penjelasan-penjelasan) dan komentar-komentar lain terhadap kitab Bulugbul Maram yang tidak kami ketahuiselain yang telah kami sebutkan, pasti ada yang lebih tahu dari seseorang yang mempunyai ilmu'.

Sebagaimana telah disinggung di atas, bahwa kitab Bulughul Maram telah mendapatkan perhatian yang sangat besar dari para ulama dan penuntut ilmu, kitab Bulugbul Maram mendapatkan banyak perlakuan istimewa dari kalangan ulama, ada yang membuat syarahnya, meneliti para perawinya sampai

\footnotetext{
${ }^{1}$ Alkatabi, M. A., Basyir al-Kiram Bi Buhīghul Marām. Surabaya : Bongkol Indah. hal.7
} 
menerjemahkannya ke dalam berbagai bahasa. Di Indonesia sendiri, kita dapat menemukan begitu banyak terjemahan kitab ini, sedikitnya ada lima belas versi terjemahan kitab Bulughul Maram ke dalam bahsa Indonesia yang peneliti ketahui, tiga di antaranya ada di tangan peneliti yaitu :

1. Terjemahan Drs. Moh. Machfuddin Aladip1985 Penerbit Toha Putra

2. Terjemahan Achmad Sunarto 2006 Penerbit CV. Karya Utama Surabaya

3. Terjemahan Yayan Surayana 2015 penerbit PT. Cordoba Internasional Indonesia Bandung

Banyaknya versi terjemahan kitab Bulughul Maram ke dalam bahasa Indonesia mengindikasikan adanya permasalahan dalam penerjemahan yang telah dilakukan para penerjemah Bulugbul Maram; sebab, jika tujuan daripada penerjemahan kitab Bulugbul Maram ke dalam satu bahasa tertentu telah tercapai oleh salah seorang penerjemah, maka diasumsikan tidak lagi diperlukan terjemahan-terjemahan yang lain dalam bahasa sasaran yang sama atau setidaknya tidak banyak versi terjemahannya. Sebagai contoh, dalam terjemahan Bulugbul Maram pada hadis nomor 5 dari bab Adab, teks sumbernya adalah sebagai berikut:

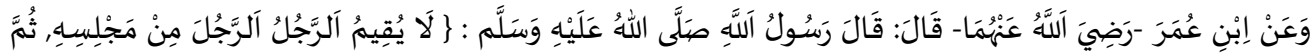

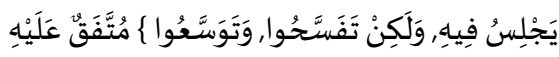

Oleh Machfuddin Aladip (hal: 742) diterjemahkan ke bahasa Indonesia menjadi:" dari ibnu Umar, ra., ia berkata: "bersabda Rasulullab saw.: "bendaknya lelaki itu tidak tetap saja duduk-duduk di tempat duduknya, akan tetapi berilah kesempatan orang lain duduk di tempat itu". (Hadits disepakati imam Bukhari dan imam Muslim) $)^{2}$.

Dari terjemahan tersebut di atas didapati beberapa permasalahan dalam penerjemahan, diantaranya: Masalah Pemilihan Makna Kata. Dalam TSa1 kata arrajulu diterjemahkan menjadi "lelaki itu". Sedangkan pada TSa2 dan TSa3 kata arrajulu diterjemahkan menjadi "seseorang". Dua makna tersebut jelas memiliki pengertian yang berbeda, sebab jika arrajulu diterjemahkan menjadi "lelaki itu" maka kata tersebut merujuk pada satu persona yang khusus, hal ini ditunjukkan oleh adanya kata tunjuk "itu" setelah nomina "lelaki" yang berfungsi untuk menunjuk atau menandai orang atau benda secara khusus. Sedangkan jika arrajulu diterjemahkan menjadi "seseorang" maka kata tersebut merujuk kepada makna yang lebih umum yang mencakup lelaki atau perempuan. Seorang penerjemah harus mengetahui makna yang mana yang dikehendaki oleh teks sumber tersebut di atas. Selanjutnya, Masalah Kesetiaan Teks Terjemahan dalam Menyampaikan Pesan yang Terkandung dalam Teks Sumber. Dari tiga terjemahan hadis tersebut di atas dapat dipahami bahwa terjemahan pertama TSa1 memuat dua pesan yaitu: 
1. Larangan bagi seorang lelaki untuk duduk-duduk saja di tempat duduknya

2. Anjuran bagi lelaki tersebut agar memberi kesempatan kepada orang lain untuk duduk di tempat itu (tempat duduknya)

Dalam menerjemahkan hadis ini, penerjemah dengan Tsa1 mengekalkan makna kata (الرَّجُجُ)/arrajulu, yaitu lelaki. Sehingga orang yang membaca terjemahan hadis ini akan memahami bahwa larangan dan anjuran pada hadis ini hanya berlaku pada lelaki saja.

Tentu terjemahan ini keliru, hal ini dibuktikan dengan penjelasan Asshan'āni mengenai hadis̉ ini bahwa hadis ini berisi larangan yang zahirnya adalah suatu pengharaman, yakni siapa saja yang lebih dulu menempati suatu tempat yang halal baik itu di masjid maupun di tempat lain untuk mengerjakan salat atau pekerjaan lain maka ia lebih berhak atas tempat itu dan haram bagi orang lain untuk mengusirnya dari tempat tersebut ${ }^{3}$.

Berdasarkan kasus tersebut di atas perlu diadakan suatu kajian yang membandingkan hasil terjemahan kitab Bulughul Maram dari berbagai macam versi agar diketahui terjemahan yang paling amanah dalam menyampaikan pesan yang terkandung dalam hadis̀-hadis yang terdapat dalam kitab Bulüghul Marām di antara terjemahan-terjemahan yang ada.

Setelah menelusuri berbagai literatur baik cetak maupun elektronik di perustakaan manual maupun perpustakaan di awan (cloud storage), ditemukan penelitian-penelitian dan kajian-kajian yang berkenaan dengan tema penelitian ini, baik tentang kitab Bulughul Maram, terjemabannya maupun yang berkaitan dengan penilaian kualitas terjemahan antara lain: (1) Yasir bin Muhammad bin Saleh Husawy $(1428 \mathrm{H})$ di dalam penelitiannya ia menjadikan mafhumul adad (kemafhuman numeralia) dan penerapan hukum yang timbul dari numeralia tersebut sebagai fokus kajiannya. Dari Kajian ini peneliti mengambil manfaat dari teori-teori yang diterapkan dalam memahami makna hadis yang mengandung unsur numeralia ${ }^{4}$. (2) Abdullah Bin Abdul Qayyum (1417H) mengkaji masalah mafhum al-mukhalafah (berkenaan dengan masalah interpretasi) dan penerapannya pada hadiś-hadis muamalat dari kitab Bulughul Maram ${ }^{5}$. (3) Muhammad Hotib (2006) fokus menganalisis diksi dalam terjemahan Bulugbul Maram pada Bab Riba. Dalam penelitiannya Muhammad Hotib berkesimpulan bahwa penerjemahan yang dilakukan A. Hasan masih dipengaruhi struktur bahasa sumber. Diksi yang digunakan dalam terjemahan A. Hasan masih kurang sesuai dengan syarat ketepatan dan kesesuaian diksi. Dalam penerjemahan, A.

3 As-Shan'ani, M. I., 2001. Subulussaläm al-mūshilatu ilā bulüghil marām. Riyad: Darul 'Ashimah. 2003. Hal:913.

${ }^{4}$ Husawy,. Mafhum al-'Adad Wa Tathbiīqātubu Min Kitāb Bulughul Maram. Makkah: Universitas Ummul Qura Saudi Arabia. 1428H. Hal. 3-7.

5 Abdulqayyum, A., 1417. Mafhum al-Mukhalafah wa at-Thathbiq 'Alaibi Min Abadis alMu'amalat Min Kitab Bulughul Maram. Makkah: Ummul Qura. Hal. أ ب 
Hasan sangat dipengaruhi oleh latar belakang pendidikannya sehingga bahasa yang digunakan dalam penerjemahan Bulughul Maram adalah bahasa Melayu ${ }^{6}$. (4) Luki Nurdiansyah (2008) memfokuskan kajian terhadap hal (keterangan keadaan) dalam bahasa Arab dan padanannya dalam bahasa Indonesia yang terdapat dalam naskah terjemahan kitab Bulughul Maram karya Drs. Machfudin Aladip. Masalah yang diangkat dalam penelitian tersebut adalah: (a) Apakah padanan hal yang ditemui pada terjemahan Bulughul Maram oleh Drs. Machfudin Aladip tepat atau tidak? Dan (b) Mengapa dan berapa banyak kesalahan yang ditemui di dalam terjemahan ini? Dalam kesimpulannya Luki Nurdiansyah mengatakan bahwa dari penelitian yang ia lakukan terhadap kesepadanan bal dalam terjemahan Bulugbul Maram karya Drs. Machfudin Aladip hanya terdapat sedikit kekeliruan dalam menerjemahkan kalimat hal. Dari 23 kalimat hal dalam kajian yang diteliti hanya terdapat enam kasus kesalahan yang dilakukan penerjemah dalam menerjemahkan kalimat hal. (5) Zamri (2014) mengkaji macam-macam makna yang dilahirkan dari uslub istifham (pola kata tanya) ditinjau dari perspektif ilmu balaghah. Di dalam penelitiannya Zamri berupaya mengungkapkan apa saja Ushlub Istifham seolah-olah hakiki tetapi tidak hakiki yang terdapat dalam hadis Rasulullah SAW dalam Kitab Bulugbul Maram Min Adillah al-Ahkam ${ }^{8}$.

Dari penelusuran dan studi pustaka yang peneliti lakukan tidak ditemukan penelitian yang mengkaji kitab Bulugbul Maram dari aspek kesashihan terjemahan, baik berkenaan dengan hasil maupun proses penerjemahan atau hasil dan proses penerjemahan sekaligus. Di dalam penelitian ini, peneliti mencoba untuk mengkaji sisi kualitas terjemahan dan metode yang digunakan dalam penerjemahan hadis-hadis kitab Bulughul Maram khususnya pada bab Kitabul Jami', hai ini dilakukan juga sebagai bentuk pertisipasi dalam pengembangan dan peningkatan ilmu khususnya di bidang penerjemahan yang dengan ini peneliti juga berdoa dan berharap kepada Allah agar usaha ini dicatat sebagai amal salih yang diterima di sisi-Nya dalam rangka berkhidmat pada syariat Islam dan pengembangan ilmu penerjemahan, khususnya dalam penerjemahan nash-nash agama Islam.

Dari latar belakang dan batasan masalah yang telah dipaparkan sebelumnya, penulis merumuskan masalah penelitian sebagai berikut, yaitu:

${ }^{6}$ Muhammad Hotib,. Analisis Diksi Terjemahan Buku Bulüghul Marām Pada Bab Riba Versi "A. Hasan". Jakarta: Universitas Islam Negeri Syarif Hidayatullah, 2006. Hal. 46.

7 Nurdiansyah, Hal Dalam Bahasa Arab Dan Padanannya Dalam Bahasa Indonesia (Analisis Terbadap Buku Terjemahan Bulugh Al-Maram Oleh Drs. Machfudin Aladip Pada Bab Thaharah). Jakarta: Universitas Islam Negeri Syarif Hidayatullah, 2008. Hal. 1-3.

8 Zamri, Studi Analisis Balaghoh Tentang Istifham Dan Makna - Maknanya Dalam Kitab Bulughul Maram Min Adillah Al - Abkam Lil Hafizh Ibnu Hajar Al-Asqalani.. Riau: Universitas Islam Negeri Sultan Syarif Kasim, 2014. Hal. ي 
Terdapat kesalahan-kesalahan pada terjemahan bulughul maram karya Moh. Machfuddin Aladip

Kajian ini bertujuan untuk mengungkapkan kesalahan-kesalahan yang ada pada terjemahan hadis-hadis di dalam kitab Bulughul Maram dan mengapa faktor apa saja yang menyebabkan kesalahan tersebut terjadi.

\section{Hasil dan Pembahasan}

Terjemahan salah ialah hasil terjemahan yang gagal mengeluarkan dan melahirkan makna atau maklumat yang sebenarnya daripada teks bahasa sumber ke dalam teks bahasa sasaran. Berikut ini akan diuraikan hadis-hadis yang terjemahannya dinilai salah.

\begin{tabular}{|c|c|c|}
\hline No. & Teks sumber & Teks sasaran \\
\hline 5 & 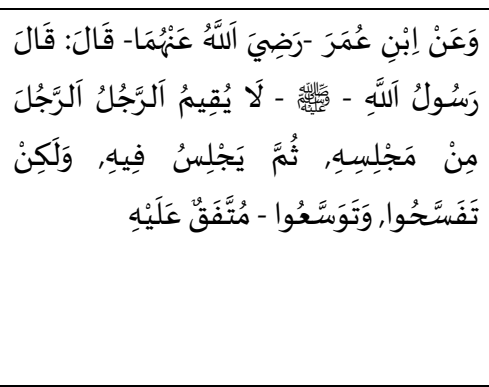 & $\begin{array}{l}\text { Dari ibnu umar, ra., ia berkata: } \\
\text { "bersabda Rasulullah saw.: } \\
\text { "Hendaknya lelaki itu tidak tetap saja } \\
\text { duduk-duduk di tempat duduknya, } \\
\text { akan tetapi berilah kesempatan orang } \\
\text { lain duduk di tempat itu". (Hadits } \\
\text { disepakati Imam Bukhari dan Imam } \\
\text { Muslim). }\end{array}$ \\
\hline
\end{tabular}

Terjemahan hadis ini tergolong salah karena makna atau yang ada pada teks sasaran menyimpang dari pesan yang terkandung di dalam teks sumber. Hal ini dibuktikan dengan fakta-fakta berikut:

1. Pembatasan kata lelaki dengan kata "itu", seolah-olah Nabi sedang bercerita tentang seseorang tertentu, padahal tidak demikian.

2. Terjadinya penghilangan padanan kata يقيم/yuqimu/, secara morfologis kata يقيم /yuqimu/ merupakan bentuk tsulätsi mazìd dari kata قام /qäma/ dengan penambahan satu huruf di awalnya yaitu hamzah yang makna aslinyasecara leksikal ialah: mendirikan (membuat sesuatu jadi berdiri). Sedangkan kata ini termasuk kata yang sering mengalami perubahan makna yang disebabkan oleh adanya kolokasi, dalam kata lain makna kata ini akan dipengaruhi oleh kata lain yang bersanding dengannya. Jika diperhatikan pada teks sumber, akan ditemui bahwa kata يقيم /yuqimu/ di dalam teks hadis tergolong fi'l muta'addiy(transitive) yang mengenai obejknya secara langsung tanpa perlu adanya bantuan harful jar yang bisa saja bermakna: 1) mendirikan (membuat sesuatu jadi berdiri), 2) mengerjakan, 3) menghujatsebagaimana tersebut di dalam kamus al-Munawwir. Untuk menentukan salah satu dari tiga makna yang tersebut di atas, harus disesuaikan dengan siyaq atau kontek kalimat yang ada. Di dalam kasus ini makna yang paling tepat untuk dipadankan dengan kata يقيم /yuqimu/ adalah 'mendirikan' atau 'membuat sesuatu jadi 
berdiri'. Melihat konteks kalimat pada teks sumber yang bercerita tentang adab-adab di dalam majelis maka kata mendirikan atau membuat sesuatu jadi berdiri boleh diganti menjadi 'mengusir'. Sebab pengusiran seseorang dari tempat yang sudah didudukinya menuntut orang yang diusir berdiri dan pindah dari tempatnya semula.

3. Adanya penambahan kata duduk-duduk yang di dalam bahasa Indonesia maknanya lebih dari sekedar duduk. Duduk-duduk dalam kamus besar bahasa Indonesia bermakna duduk santai atau bersantai

4. Penggantian padanan kata مِ $/ \mathrm{min} /$ yang secara leksikal bermakna 'dari' diterjemahkan menjadi 'di'.

5. Penghilangan klausa ثم يجلس فيه/tsumma yajlisu fibi/ yang jika diterjemahkan secara literal bermakna 'kemudian ia duduk di situ (tempat dudu orang yang pertama).

Dalam terjemahan hadis ini penerjemah menggunakan metode terjemahan bebas dengan strategi yang dinamis, dimana penerjemah tidak lagi terikat dengan struktur dan pola bahasa teks sumber dan melakukan penghilangan pada beberapa bagian dari teks sumber.

Terjemahan yang tepat untuk hadis di atas adalah: "janganlah seseorang mengusir orang lain dari tempat duduknya, kemudian ia duduk di tempat itu (tempat duduk orang yang diusir tadi), akan tetapi carilah tempat yang lebih lapang dan luas".

\begin{tabular}{|c|c|c|}
\hline No. & Teks sumber & Teks sasaran \\
\hline 30 & 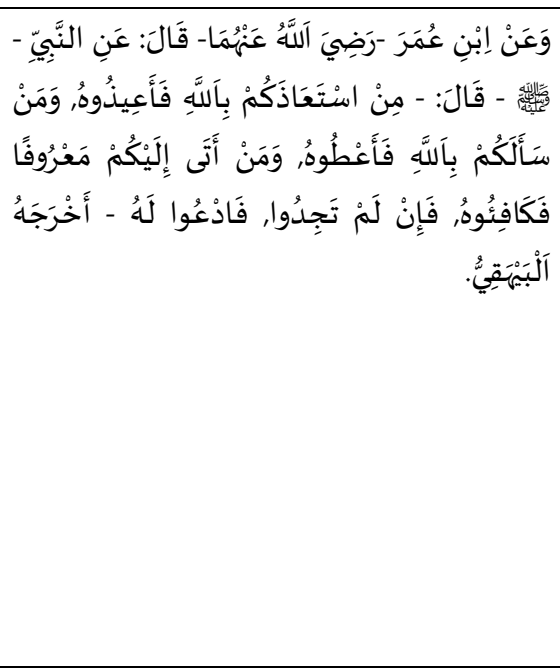 & $\begin{array}{l}\text { Dari Ibnu Umar, ra., ia berkata: } \\
\text { "Bersabda Rasulullah saw.: } \\
\text { "Barang siapa yang meminta } \\
\text { perlindungan kepadamu karena } \\
\text { Allah, maka lindungilah ia, dan } \\
\text { barang siapa yang meminta } \\
\text { kepadamu karena Allah, maka } \\
\text { berilah, dan barang siapa yang } \\
\text { mendatangi berbuat yang } \\
\text { ma'ruf, maka penuhilah. Jika } \\
\text { kamu tidak menemukannya, } \\
\text { maka ajaklah mereka berbuat } \\
\text { kebaikan". (Hadits dikeluarkan } \\
\text { oleh Imam Baihaqi). }\end{array}$ \\
\hline
\end{tabular}

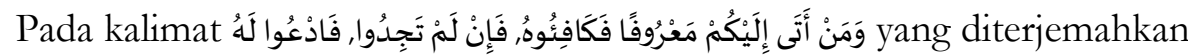
menjadi "dan barang siapa yang mendatangi berbuat yang ma'ruf, maka penuhilah. Jika kamu tidak menemukannya, maka ajaklah mereka berbuat 
kebaikan". Pada penggalan hadis ini terdapat kesalahan penerjemahan yang dapat diuraikan sebagai berikut.

Jumlah syarthiyah وَمَنْ أَثَى إِلَيْكُمْ مَعْرُوفًا فَكَافِيُوهُ diterjemahkan menjadi "mendatangi berbuat yang ma'ruf, maka penuhilah ". Susunan kata pada kalimat ini tebilang tidak baik sehingga sulit bagi pembaca atau orang yang mendengarkan kalimat ini untuk memahami maksud daripada kalimat tersebut. Jika kalimat tersebut diuraikan maka akan ditemui kerancuan pada klausa "mendatangi berbuat yang ma'ruf" sebab kata mendatangi merupakan kata kerja transitif yang memerlukan adanya objek, sedangkan "berbuat yang ma'ruf” tidak dapat dipahami sebagai objek, sebab kata berbuat juga merupakan kata kerja transitif dimana objeknya adalah frasa "yang ma'ruf", sehingga kalimat ini sulit dipahami kecuali jika verba "berbuat" diganti menjadi nomina "perbuatan" maka makan kalimat tersebut masih dapat dimaklumi sehingga menjadi "mendatangi perbuatan yang ma'ruf dalam artian "mengerjakan perbuatan yang ma'ruf". Namun yang demikian itu juga tidaklah tepat, karena padanan kata "berbuat" ataupun "perbuatan" sebenarnya tidaklah wujud pada teks sumber, artinya dalam hal ini penerjemah menggunakan Teknik penambahan dalam menerjemahkan fi'l madhi أَثَ / atäl.

Pemilihan kata "mendatangi" untuk menerjemahkan kata أَتَى tidaklah tepat. Secara leksikal memanglah kata ini memiliki beberapa makna di antarnya adalah "datang" atau "mendatangi". Akan tetapi makna kata ini akan selalu berubah dengan adanya kata yang mengikutinya. Kata datang di dalam Bahasa Indonesia merupakan kata kerja intransitive yang tidak memerlukan objek,

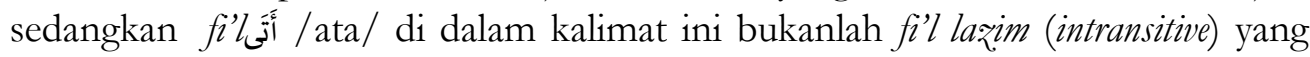
tidak memerlukan objek atau memerlukan bantuan harf jar untuk sampai kepada objeknya, melainkan ia merupakan fi'l muta'addiy yang mengenai objeknya secara langsung tanpa bantuan harf jar. Hal ini dibuktikan dengan adanya kata yang manshub sebagai maf'ul bibi (objek) yaitu kata مَعْرُوفًا /ma'rufan/ yang bermakna

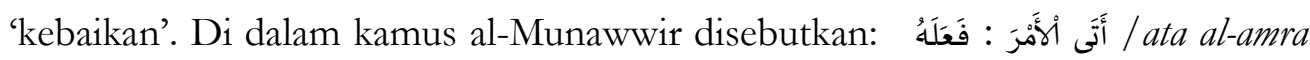
= fa'alabu/ mengerjakan, melakukan suatu perbuatan/perkara".

Selain penambahan, kesalahan dalam terjemahan kalimat ini juga disebabkan oleh adanya penghilangan padanan frasa إِلَيْكُمْ /ilaikum/ yang bermakna 'kepada kamu'.

Sedangkan klausa فَكَافِيُوهُ/fakäfiühu/ yang diterjemahkan menjadi 'maka penuhilah' juga mengalami penghilangan satu padanan kata yang membentuknya yaitu dhamir sُ/hu/'dia'. Selain itu pemilihan kata 'penuhilah' tidak sepadan

9 Munawwir,. Kamus al-Munawwir Arab-Indonesia Terlengkap. Surabaya: Pustaka Progressif, 2007. Hal. 6 


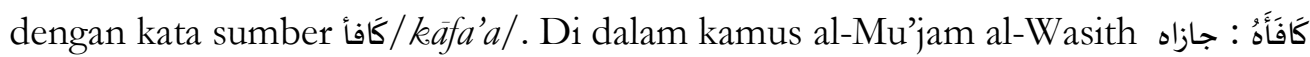
/ keáfa-ahu $=j \bar{a} a \bar{a} h u /$ membalasnya. ${ }^{10}$

Begitupun pada kalimat فَادُعُوا لَهُ / fad'ülahu/ yang diterjemahkan menjadi 'maka ajaklah mereka berbuat kebaikan'; kalimat ini merupakan jawab syarth dari jumlah syarthiyyah yang sebelumnya yaitu فَإِنْ لَمْ تَجِدُدو /fa in lam tajidū/ 'Jika kamu tidak menemukannya'. Masalah muncul dengan adanya penambahan pronomina 'nya' dalam terjemahan kata تَجْدُوا /tajidu/.

Di dalam teks sasaran frasa 'menemukannya' merupakan frasa yang mengandung unsur pronomina yaitu "nya" yang dalam hal ini hanya dapat dipahami sebagai objek dari verba 'menemukan', sedangkan pronomina 'nya' ini - yang menyatakan milik, pelaku, atau penerima - haruslah memiliki referen yang telah disebutkan sebelumnya. Sedangkan di awal tidak ada satu kata pun yang dapat referen/rujukan untuk pronomina 'nya'. Jadi pada kalimat "Jika kamu tidak menemukannya" pronomina "nya" pada kalimat tersebut merupakan penambahan yang tidak perlu.

Sedangkan pada kalimat "maka ajaklah mereka berbuat kebaikan" juga terjadi kekeliruan memilih kata-kata untuk menerjemahkan klausa فَفَادُعُوا لَهُ/fad'u lahu/dalam kasus ini perlu dicermati bahwa kata دعا /da'a/ yang secara leksikal bermakna mengajak atau memanggil, jika bersanding dengannya harful jar $\mathbf{l i}$, maka maknanya berubah menjadi mendoakan kebaikan bagi seseorang.

Dengan demikian jelas kekeliruan dalam terjemahan kalimat tersebut, hal ini dapat dibuktikan dengan menerapkan metode penerjemahan kata perkata dari kalimat tersebut, sehingga akan ditemui makna dari setiap kata yang ada pada kalimat tersebut sebagai berikut:

\begin{tabular}{|c|c|c|c|c|}
\hline فَكَافِيُوهُ & مَعْرُوفًا & إلَيْيُكُمْ & أَتَى & وَمَنْ \\
\hline $\begin{array}{l}\text { Maka balaslah } \\
\text { dia dengan } \\
\text { kebaikan yang } \\
\text { setimpal }\end{array}$ & Kebaikan & Kepada kamu & $\begin{array}{l}\text { Datang/ } \\
\text { melakukan }\end{array}$ & $\begin{array}{c}\text { Dan barang } \\
\text { siapa }\end{array}$ \\
\hline
\end{tabular}

Dengan menggunakan metode terjemah kata demi kata sebagaimana tersebut di atas dapat dipahami bahwa maksud daripada hadis tersebut ialah: "barang siapa yang berbuat kebaikan kepadamu maka balaslah ia dengan kebaikan yang setimpal, namun jika kamu tidak mendapatkan sesuatu yang dapat kau berikan sebagai balasan kepada orang yang telah berbuat baik kepadamu maka doakanlah ia agar mendapat kebaikan".

10 Ibrahim, dkk, al-Mu'jam al-Wasith, Mesir: Maktabah Asysyuruq Addauliah, 2004. hal. 
Hal ini dibuktikan dengan redaksi hadis semisal yang diriwayatkan oleh Imam Ahmad yang berbunyi:

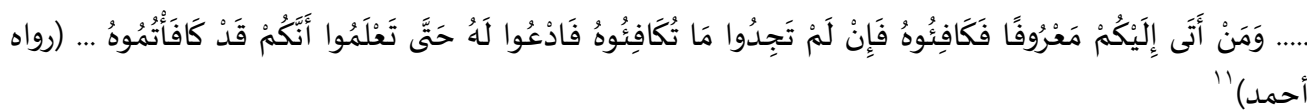

"Barang siapa yang berbuat kebaikan kepadamu maka balaslab ia dengan kebaikan yang setimpal, namun jika kamu tidak mendapatkan sesuatu yang dapat kau berikan sebagai balasan kepadanya maka doakanlah ia agar mendapat kebaikan, sampai kau tabu bahwa kau benar-benar telah membalasnya".

\begin{tabular}{|c|c|c|}
\hline No. & Teks sumber & Teks sasaran \\
\hline 37 & 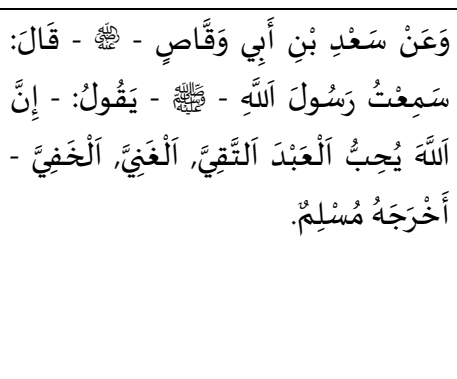 & $\begin{array}{l}\text { Dari Sa'ad putera Abu Waqash,ra., ia } \\
\text { berkata: "Aku pernah mendengar } \\
\text { Rasulullah saw. Allah mencintai } \\
\text { "Sesungguhnya bersabda: } \\
\text { hambaNya yang bila berjumpa dengan } \\
\text { orang yang kaya, ia menyembunyikan } \\
\text { kekayaan darinya". (Hadits dikeluarkan } \\
\text { oleh Imam Muslim). }\end{array}$ \\
\hline
\end{tabular}

Pada terjemahan hadis ini ditemukan sebuah kasus yang menarik untuk menjadi perhatian, hal ini akan diuraikan sebagai berikut:

Jika diperthatikan dengan seksama tampak bahwa struktur kata dalam kalimat terjemahan hadis ini sama dengan struktur kata yang membentuk kalimat dalam teks sumber. Hanya saja penerjemah melakukan penambahan pada beberapa kata, selain itu Teknik transposisi dalam menerjemahkan juga digunakan.

Pada terjemahan kata آَّعَبْدَ/al-'abda/ terjadi penambahan pronomina "Nya" yang merujuk kepada lafžbul jalalah (Allah), dalam kasus ini penambahan tersebut tidak memberikan dampak yang signifikan dalam perubahan makna, sebab secara otomatis dapat dipahami.

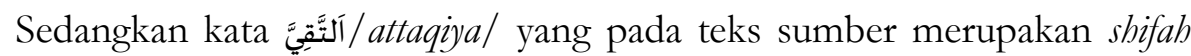
musayabbihah lismil fa'il yang masuk dalam kelas adjektiva dimana kedudukannya di dalam jumlah tersebut adalah sebagai na'tun, mengalami pergeseran (trasnposisi) menjadi frasa verba "bila berjumpa". Hal ini dipandang sebagai sebuah kesalahan dalam terjemahan yang diduga penyebabnya adalah bahwa penerjemah keliru dalam membaca atau memahami kata آَتَّقَيَّ/attaqiya/ dimana penerjemah memahaminya sebagai fi'l madhi الَْتَفَ/iltaqä/ yang maknanya adalah "berjumpa".

11 Hanbal, Musnadul Imam Ahmad bin Hanbal. Beirut: Muassasaturrisalah, 1999. hal. $266 / 9$ 
Hal ini mungkin dikarenakan huruf-huruf yang membentuk kedua kata tersebut sama yaitu hamz̧ah washal (I), làm (J), tāa (ت) , qä́) dan yā (ي) dan susunannya yang juga sama. Inilah yang diduga menjadi sebab terjadinya

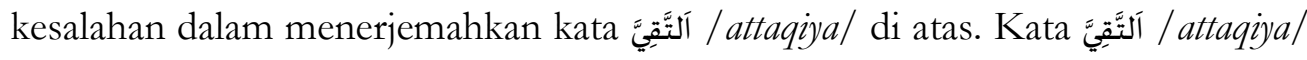
merupakanshifah musaybbihah yang dibentuk dari asal tsulatsi وقى /waqā/ bermakna

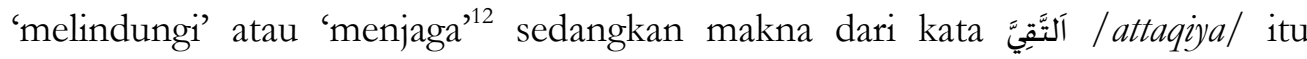
sendiri adalah 'yang bertakwa'. Sedangkan الَْتَّى / iltaqä/ adalah sebuah fi'l yang dibina dengan bentuk khumasiy dari asal tsulatsi لقي القئlaqiya/ bermakna 'berjumpa"13.

Dari uraian di atas sangat jelas terlihat kesalahan pada terjemahan kata آكَتَّيَّ /attaqiya/ di dalam hadis tersebut.

Berikutnya kesalahan juga terjadi dalam menerjemahkan kata آلْخَفِيَّ /alkhafiya/. Di sini penerjemah menerjemahkan kata tersebut dengan merubah kelas kata dari shifah/adverbia menjadi verba, artinya penerjemah menggunakan teknik transposisi, dimana penerjemah menukar kelas kata dari adverbia pada teks sumber menjadi verba dalam teks sasaran sampai di masalah belum terlihat. Namun jika dicermati masalah terjadi dengan adanya penambahan kata 'kekayaannya darinya' pada teks terjemahan. Hal ini dapat dilihat pada tabel berikut:

\begin{tabular}{|c|c|c|}
\hline $\begin{array}{c}\text { Teks } \\
\text { sumber }\end{array}$ & Teks sasaran & Makna leksikal \\
\hline الْخَفيَّ & $\begin{array}{c}\text { ia menyembunyikan } \\
\text { kekayaan darinya }\end{array}$ & $\begin{array}{c}\text { Yang diam-diam, sembunyi- } \\
\text { sembunyi (secara rahasia) }\end{array}$ \\
\hline
\end{tabular}

Dari tabel di atas kita melihat bahwa sebuah nomina الْخَفِيَّ /alkhafiyal yang juga merupakan na'tun (sifat) bagi kata al'abda pada teks sasaran berubah menjadi Subjek (ia) + Predikat (menyembunyikan) + Objek (kekayaan) + Keterangan (darinya).

Jika dilihat dengan seksama, kedudukan kata الََْفِيَّ /alkhafiya/ pada hadis tersebut secara sintaktis adalah sama dengan kata آَتَّقَيَّيَّ /attaqiya/ yang telah dibahas sebelumnya, yakni sebagai na’tun (sifat) yang menjelaskan kata آَّعَبَْ /al'abda/. Secara leksikal kata الََْفِيَّalkhafiya/ sebagaimana tertera pada tabel di atas

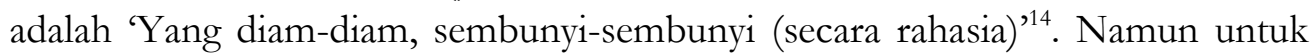
mengetahui makna sesungguhnya yang dikandung oleh kata tersebut dapat

\footnotetext{
${ }^{12}$ Munawwir, Kamus al-Munawwir, hal.1577

13 Munawwir, Kamus al-Munawnir, hal.1282.

14 Munawwir, Kamus al-Munawnir, hal. 357
} 
merujuk kepada syarah dari para ulama mengenai hadis terebut. Al-Shan'ani menjelaskan ${ }^{15}$ :

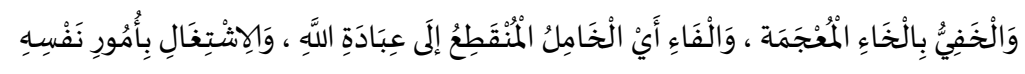

'Kata alkhafizu dengan kha'mu'jamah dan fa' yakni al-khamil yaitu orang yang tidak ternama yang fokus beribadah kepada Allah serta menyibukkan diri dengan urusan dirinya sendiri'.

Sedangkan redaksi terjemahan hadis tersebut berbunyi: "Sesungguhnya Allah mencintai hambaNya yang bila berjumpa dengan orang yang kaya, ia menyembunyikan kekayaan darinya". Maksud dan pesan yang terkandung pada redaksi terjemahan hadis ini menjadi tidak jelas disebabkan adanya perubahanperubahan yang tidak tepat pada beberapa kata sebagaimana diterangkan di atas.

Dengan uraian di atas terjemahan hadis tersebut dapat diperbaiki dengan redaksi yang lebih sederhana yang in syaa Allah makna yang dikandung akan dapat dipahami dengan mudah misalnya diterjemahkan menjadi:

"Sesunggubnya Allah mencintai hamba yang bertakwa, kaya dan merabasiakan (ibadahnya)" penambahan frasa 'ibadahnya' perlu dilakukan sebab kata 'merahasiakan' merupakan verba transitif yang memerlukan objek, sedangkan kata 'ibadah' dipilih merujuk pada keterangan Imam as-Shan'ani dalam syarah hadis tersebut.

\begin{tabular}{|c|c|c|}
\hline No. & Teks sumber & Teks sasaran \\
\hline 39 & 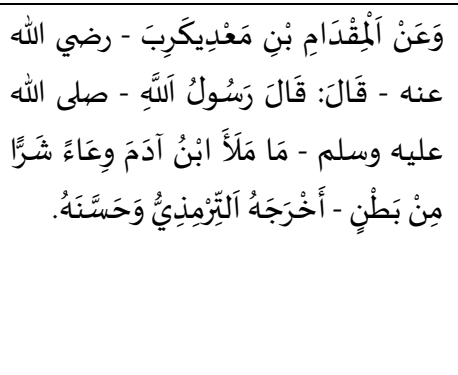 & $\begin{array}{l}\text { Dari Miqdam putera Ma'dikariba, ra., ia } \\
\text { berkata: "Bersabda Rasulullah saw.: } \\
\text { "Tidaklah akan merasa banyak perut } \\
\text { anak Adam atas kejahatan". (Hadits } \\
\text { dikeluarkan oleh Imam Turmudzi dan } \\
\text { dihasankannya). Maksudnya: "Manusia } \\
\text { itu selalu saja merasa kekurangan" } \\
\text { (penerjemah). }\end{array}$ \\
\hline
\end{tabular}

Kasus yang terjadi pada terjemahan hadis nomor 39 ini juga ada kemiripan dengan hadis yang sebelumnya, yaitu adanya kekeliruan dalam menerjemahkan beberapa kata. Tampaknya penerjemah kali ini tidak lagi terikat dengan struktur dan pola bahasa sumber, sebab teks pada teks sasaran strukturnya sudah jauh berbeda dari struktur teks sumber. Namun kekeliruan terjadi saat kata 'ملأlmala-a/ diterjemahkan menjadi 'merasa banyak', dan adanya penghilangan padanan kata وعاء/wi'a'/ yang secara leksikal berarti 'wadah'16.

15 As-Shan'ani, Subulussalām al-Mūshilatu ilā bulüghil marām. hal. 342

${ }^{16}$ Munawwir, Kamus al-Munawwir, hal.1569 
Selain itu struktur kalimat pada teks sasaran juga menyelisihi pola struktur kaliamat yang baku dalam bahasa Indonesia, pola kaliamat pada hasil terjemahan ini adalah Predikat + Subjek + Keterangan, ditambah lagi antara predikat yang disandarkan kepada subjek dan keterangan tidak memiliki hubungan yang logis baik secara hakiki maupun secara majazi. Adapun keterangan yang diberikan oleh penerjemah dengan menambahkan "maksudnya: "Manusia itu selalu saja merasa kekurangan". Ini juga menyimpang dari pada pesan sebenarnya yang terkandung di dalam hadis.

Maksud yang sebenarnya dari hadis tersebut sebagaimana diterangkan oleh Imam as-Shan'ani adalah: "tidak ada wadah yang diisi anak Adam (manusia) yang lebih buruk dari perut" kemudian beliau menambahkan bahwa hadis tersebut mengandung celaan terhadap sikap berlebihan dalam hal makan dan kondisi perut yang kenyang dan penuh ${ }^{17}$. Atau boleh juga dengan menggunakan metode literal seperti "tidaklah seorang anak Adam mengisi wadah yang lebih buruk dari perut".

\begin{tabular}{|c|c|c|}
\hline No. & Teks sumber & Teks sasaran \\
\hline 49 & 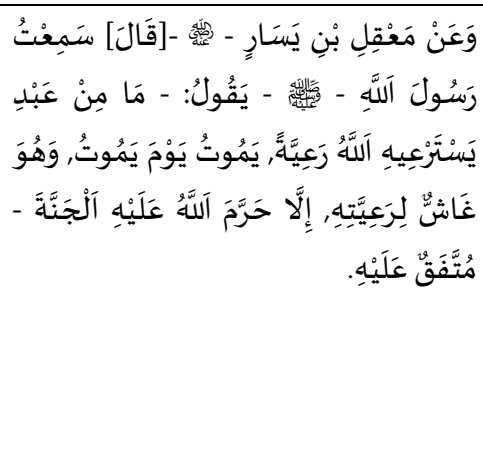 & $\begin{array}{l}\text { Dari Ma'qul putera Yasar, ra., ia } \\
\text { berkata: "Aku pernah mendengar } \\
\text { Rasulullah saw. Bersabda: "Tidaklah } \\
\text { seorang hamba Allah yang diserahi } \\
\text { tugas memimpin rakyat, lalu mati } \\
\text { dalam keadaan sedang menipu } \\
\text { rakyatnya, kecuali akan } \\
\text { dimasukkan terhadapnya sorga". } \\
\text { (Hadits disepakati Imam Bukhari dan } \\
\text { Imam Muslim). }\end{array}$ \\
\hline
\end{tabular}

Pada terjemahan hadis ini ada klausa yang diterjemahkan secara semantis yaitu يَمُوتُ يَوْمَ يَمُوتُ /yamutu yauma yamutu/ diterjemahkan menjadi 'lalu mati', meskipun ada frasa pada teks sumber yang dihilangkan padanannya, namun hal itu tidak memberi pengaruh yang signifikan dalam perubahan makna. Sampai di sini belum tampak ada permasalahan yang berarti dalam hasil terjemahan ini.

Namun jika diteruskan kepada bagian yang terakhir, akan dijumpai klausa yang salah diterjemahkan sehingga pesan hadis ini tidak dapat dipahami

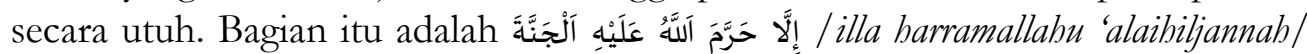
yang diterjemahkan menjadi "kecuali akan dimasukkan terhadapnya sorga". Bagian ini sama sekali tidak dapat dipahami oleh pembaca terjemahan ini. Kata / حَرَّمَ / harrama/ diterjemahkan menjadi 'dimasukkan', padahal secara leksikal pun maknanya 'melarang'. 
Maksud dari hadis tersebut di atas adalah bahwa siapa saja yang diangkat menjadi pemimpin atas individu atau sekelompok orang, kemudian dia meninggal dalam keadaan menipu orang yang dipimpinnya maka Allah tidak akan memasukkannya ke dalam surga ${ }^{18}$.

\begin{tabular}{|c|c|c|}
\hline No & Teks sumber & Teks sasaran \\
\hline 50 & 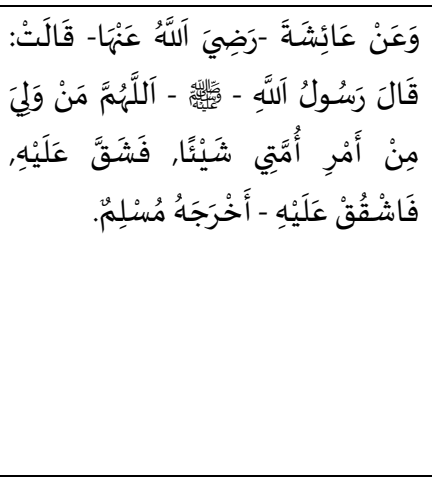 & $\begin{array}{l}\text { Dari Aisyah, ra., ia berkata: } \\
\text { "Bersabdalah Rasulullah saw. (dalam } \\
\text { do'anya): " Allabumma Man Waliya Min } \\
\text { Amri Ummatii Sya-Iaan Fasyaqqa 'Alaibim, } \\
\text { Fasyfuq Alaihi". (Artinya: "Ya Allah, } \\
\text { Berilah kemudharatan kepada orang } \\
\text { yang telah menyusahkan urusan } \\
\text { ummatku, padahal ia diberi tugas } \\
\text { mengusirnya". (Hadits dikeluakan oleh } \\
\text { Imam Muslim). }\end{array}$ \\
\hline
\end{tabular}

Pada terjemahan hadis ini strategi penerjemahan literal diterapkan dan menggunakan teknik penambahan. Penambahan dimaksud berlaku pada kalimat gولي/waliyal. Kata ولي/waliyal merupakan fil madhi (verba) yang bermakna 'menguasai' atau 'mengurus'.

Kesalahan yang terjadi pada terjemahan hadis ini terdapat pada bagian akhirnya, yaitu "padahal ia diberi tugas mengusirnya" kalimat ini terlihat tidak memiliki hubungan yang logis dengan kata-kata yang tersusun sebelumnya. Kesalahan ini mungkin terjadi karena kesalahan ketik atau cetak yang mungkin maksudnya adalah "padahal ia diberi tugas mengurusinya". Namun demikian, jika hal itu dipandang sah, maka sesungguhnya penyimpangan pesan masih saja terjadi, sebab di dalam do'a nabi tersebut berisi ancaman bagi siapa saja yang mengurusi perkara atau urusan kaum muslimin namun ia mempersulit urusan mereka. Ancaman ini berlaku secara mutlak karena tidak ada dalil yang mengikatnya. Jadi penambahan kalusa "ia diberi tugas mengurusinya" tidaklah perlu bahkan dapat membuat makna hadis tersebut menjadi menyimpang dari maksud yang sebenarnya.

Terjemahan yang lebih tepat untuk hadis di atas adalah sebagai berikut: "ya Allah, siapa saja yang mengurus suatu urusan di antara urusan-urusan ummatku namun dia mempersulit mereka, maka persulitlah dia". Atau boleh juga menerapkan teknik reduksi menjadi "ya Allah, persulitlah siapa saja yang mempersulit urusan umatku"

18 As-Shan'ani, Subulussalàm Al-mūshilatu ilà bulüghil marām. Hal. ${ }^{4}$ \&). 


\begin{tabular}{|c|c|c|}
\hline No. & Teks sumber & Teks sasaran \\
\hline 51 & 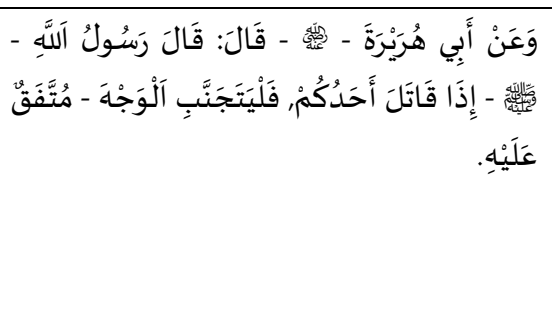 & $\begin{array}{l}\text { Dari Abu Hurairah, ra., ia berkata: } \\
\text { "Bersabda Rasulullah saw.: " Jika } \\
\text { saling membunuh (berkelahi) } \\
\text { seseorang diantara kamu, maka } \\
\text { tutupilah mukanya". (Hadits } \\
\text { disepakati Imam Bukhari dan Imam } \\
\text { Muslim). }\end{array}$ \\
\hline
\end{tabular}

Pada hadis nomor 51 ini, juga menerapkan metode penerjemahan literal dengan teknik harfiah. Kesalahan dalam terjemahan terjadi pada pemadanan

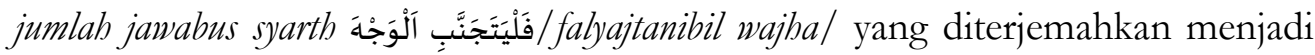
"maka tutupilah mukanya".

Klausa فَلَيَتَجَنَّبَ/falyajtanib/ terdiri dari empat kata: (1) ف /fa/ (2) lamul amri (3) fi'l mudhari' يجتنب/yajtanib/ dan (4) dhamir mustatir هو/huwwa/. Klausa ini merupakan klausa perintah bagi orang ketiga karena fi'il mudhari' yajtanib didahului oleh lamul amri, maksudnya agar orang yang terlibat perkelahian atau orang yang ingin menyerang orang lain hendaklah ia menghindari wajah (lawannya) jangan sampai menyentuh atau mencederainya. Namun pada teks sasaran ditemukan perintah kepada orang kedua dengan klausa "maka tutupilah mukanya" jelas bagian yang terakhir ini tidak memiliki hubungan dengan bagian yang sebelumnya dan tidak memandang konteks internal kalimat, oleh sebab itu terjemahan ini diniali salah. Selain itu klausa ini juga menyisakan pertanyaan, muka siapa yang harus ditutupi, dan untuk apa ditutupi?

Hal ini dapat dibuktikan dengan keterangan imam as-Shan'ani bahwa beliau mengatakan: 'di dalam satu riwayat disebutkan: "jika salah seorang dari kalian memukul" dan dalam riwayat lain "janganlah menampar wajah"19.

Dari keterangan as-Shan'ani di atas dapatlah dipahami bahwa pesan daripada hadis tersebut adalah agar seseorang yang hendak memukul orang lain atau terlibat pertengkaran dengan orang lain menghindari wajah lawannya, sehingga ia tidak menampar atau mencederai wajah lawannya itu.

\begin{tabular}{|c|c|c|}
\hline No. & Teks sumber & Teks sasaran \\
\hline 58 & 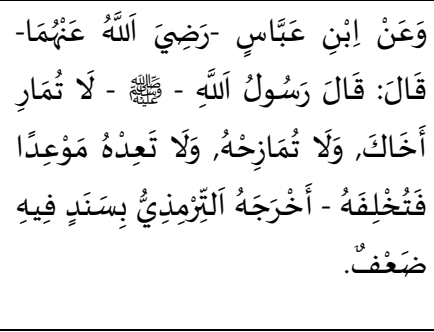 & $\begin{array}{l}\text { Dari Ibnu Abbas, ra., ia berkata: } \\
\text { "Bersabda Rasulullah saw.: "Janganlah } \\
\text { kamu memutus perkataan saudaramu, } \\
\text { (berkelahi), dan janganlah kamu } \\
\text { mengolok-oloknya serta jangan kamu } \\
\text { berjanji, sedang kamu tidak bisa } \\
\text { memenuhinya". (Hadits dikeluarkan oleh }\end{array}$ \\
\hline
\end{tabular}

19 As-Shan'ani, Subulussalām Al-mūshilatu ilà bulüghil marām. Hal.366 


\begin{tabular}{|l|l|l|}
\hline & $\begin{array}{l}\text { Imam Turmudzi dengan sanad yang } \\
\text { lemah). }\end{array}$ \\
\hline
\end{tabular}

Penerjemahan hadis nomor 55 ini menerapkan strategi penerjemahan dinamis, sebab penerjemah tidak lagi terikat dengan makna leksikal dari setiap kata pada teks sumber. Contohnya, pada pemadanan beberapa kata yaitu: (1) kata تُمَارِ/tumaril yang diterjemahkan menjadi 'memutus perkataan' atau 'berkelahi'. Secara leksikal kata ini merupakan fi'l madbi yang disandarkan pada dhamir mustatir "anta" (kata ganti orang kedua) yang bermakna 'engaku berdebat'. Namun kata yang dipilih oleh penerjemah adalah 'memutus perkataan' yang kemudian diterangkan di dalam kurung dengan 'berkelahi', makna dari kata berkelahi tentu lebih dari 'berdebat', di sini penerjemah menggunakan kalimat tersebut karena perdebatan yang di dalamnya pasti ada sikap memutus perkataan orang lain dapat menimbulkan perkelahian antara dua orang yang berdebat itu.

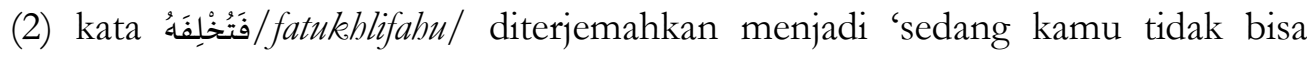
memenuhinya (janji)'.

Terjemahan ini tergolong kurang akurat sebab konteks hadis ini bercerita tentang larangan dari nabi kepada setiap mulsim untuk mengingkari janji. sedangkan terjemahan tersebut seolah-olah berisi pesan agar seseorang tidak membuat janji padahal dia tidak dapat memenuhi janji itu, dalam kondisi yang normal memanglah dimaklumi jika seseorang tidak dapat memenuhi janji mengapa ia berjanji. Dari sini dimaklumi bahwa yang dilarang sebenarnya adalah mengingkari janji, jadi larangan itu berkaitan dengan mengingkari janji dan bukan dengan janji itu sendiri.

\begin{tabular}{|c|c|c|}
\hline No. & Teks sumber & Teks sasaran \\
\hline 73 & 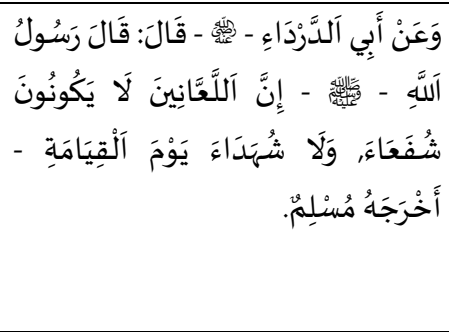 & $\begin{array}{l}\text { Dari Abu Darda',ra., ia berkata: } \\
\text { "Bersabda Rasulullah saw.: “Orang- } \\
\text { orang yang terlaknat itu tidak } \\
\text { mempunyai hak syafa'at diriku dan } \\
\text { tidak punya hak mengajukan saksi } \\
\text { pada hari kiamat". (Hadits dikeluarkan } \\
\text { oleh Imam Muslim). }\end{array}$ \\
\hline
\end{tabular}

Dalam kasus hadis nomor 73 ini juga terjadi kesalahan dalam memilih padanan kata آلَّعَانِينَ/alla'anina/ yang diterjemahkan menjadi 'Orang-orang yang terlaknat' dan juga pada kata شُفَعَاءَ/syufa'a'/ yang diterjemahkan menjadi 'mempunyai hak syafa'at diriku', sehingga mengakibatkan penyimpangan dalam menyampaikan pesan yang terkandung di dalam teks sumber.

Kata آلَلَعَانِينَ/alla'anina/ adalah bentuk shighah mubalaghah dari ism fa'il الاعِن/älin/ yang artinya orang yang melaknat. Sedangkan آلَلَعَانِ/an/ berarti orang yang suka melaknat atau mengutuk. Dalam teks terjemahan ditemukan kata 
آَلََََّانينَ/alla'anina/ diterjemahkan menjadi 'Orang-orang yang terlaknat', hal ini sangat menyimpang dari makna yang sebenarnya sebab kata yang benar untuk 'Orang-orang yang terlaknat' adalah الملمعونون / almal'ūnun/.

Berikutnya kata شُشَفَاء

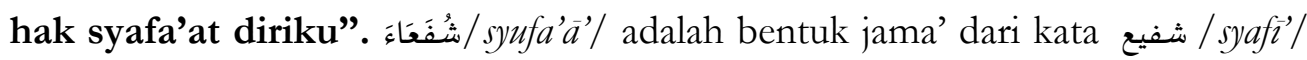
berarti 'yang memberi syafaat'. Namun di dalam teks terjemahan pemadanan dilakukan dengan cara transposisi yakni mengganti katergori صفة مشبهة لاسم الفاعل shifah musyabbihah lismil fail menjadi صفة مشبهة لاسم المفعول shifah musyabbihah ilimil maf'ul yang mengakibatkan penyelewengan makna, dari "orang yang memberi syafaat" menjadi "orang yang mendapat syafaat". Tentulah hal ini sangat jelas penyelewengannya.

Begitupun pada kata شُهَدَاءَ/syubada/ diterjemahkan menjadi 'punya hak mengajukan saksi'. Kata شُشَدَدَاءَ/syubada/ juga merupakan bentuk jamak dari kata شهيد/syahid/ yang secara leksikal berarti 'saksi' atau 'orang yang gugur sebagai syahid (di jalan Allah). Namun pada teks terjemahan dimenemukan penambahan yang menyebabkan penyimpangan makna dari kata شهيد/syabid/itu sendiri, dalam hal ini penerjemah juga menerapkan teknik transposisi dimana beliau menerjemahkan kata ini yang sejatinya berbentuk sifah musyabbihab lismil fa'il yang kelas katanya tergolong nomina pada teks sumber menjadi verba 'hak mengajukan saksi' pada teks sasaran.

Untuk mengetahui maksud daripada hadis tersebut di atas imam alShan'ani telah menerangkan tiga makna yang dinukil dari para ulama yaitu ${ }^{20}$ :

1. Orang-orang yang suka melaknat tidak akan menjadi orang-orang yang dapat memberi syafaat di hari kiamat saat kaum mukminin diizinkan untuk memberi syafaat kepada saudara-saudara mereka dan tidak pula dapat menjadi saksi atas ummat-ummat terdahulu atas dakwah yang disampaikan para rasul kepada mereka.

2. Orang-orang yang suka melaknat tidak sah diangkat menjadi saksi (di pengadilan), dan jika mereka menjadi saksi maka kesaksian mereka ditolak karena kefasikan mereka, sebab banyak melaknat merupakan dalil (tanda) dari sikap meremehkan dalam agama.

3. Orang-orang yang suka melaknat tidak akan diberi rizki berupa mati syahid (kematian di jalan Allah).

Dengan demikian tampaklah kesalahan dalam terjemahan hadis ini, sebab pesan yang dikandung di dalam teks sasaran menyimpang dari maksud teks sumber.

20 Subulussalam, hal. 367 


\begin{tabular}{|c|c|c|}
\hline No. & Teks sumber & Teks sasaran \\
\hline 82 & 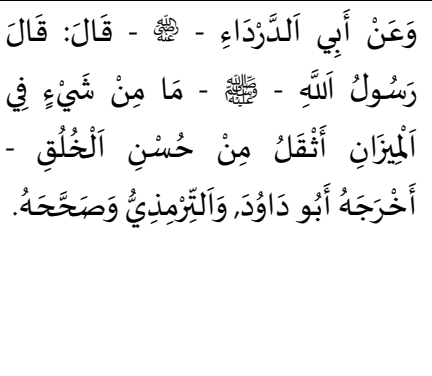 & $\begin{array}{l}\text { Dari Abu Darda', ra., ia berkata: } \\
\text { "Bersabda Rasulullah saw.: "Tidak ada } \\
\text { sesuatupun yang dapat memberatkan } \\
\text { seseorang, kecuali budi pekerti baik". } \\
\text { (Hadits dikeluarkan oleh Imam Abu } \\
\text { Daud dan Imam Turmudzi). Iman } \\
\text { Turmudzi menyatakan "Shahihnya" } \\
\text { hadits ini. }\end{array}$ \\
\hline
\end{tabular}

Terjemahan teks hadis ini dinilai salah karena ada sebuah frasa preposisional pada teks sumber yang tidak diterjemahkan pada teks sasaran yaitu frasa في آَمْيًَان /fil-mizan/ frasa ini terdiri dari dua kata yaitu 'di/pada' dan آَمْيزَانِ / almizan/ 'timbangan'.

Selain itu pada teks terjemahan ini juga tampak bahwa konteks dien atau agama tidak menjadi pertimbangan dalam penerjemahan, dalam artian bahwa terjemahan ini statis dan sangat terikat dengan teks sumber. Di dalam konteks dien dalam hal ini agama Islam yang dimaksudkan dengan timbangan dalam nas hadis tersebut di atas adalah timbangan amal perbuatan manusia pada hari kiamat. Timbangan tersebut sebagaimana dijelaskan para ulama adalah timbangan atau alat untuk menimbang yang hakiki yang benar-benar terdiri dari lengan dan dua piring timbangan.

Hal ini dibuktikan dengan adanya dalil-dalil lain yang menyatakan bahwa amal perbuatan dan juga perkataan manusia akan ditimbang pada hari kiamat nanti. Di antaranya adalah sabda Nabi shallallabu 'alaibi wa sallam di dalam Sahih Bukhari ${ }^{21}$ :

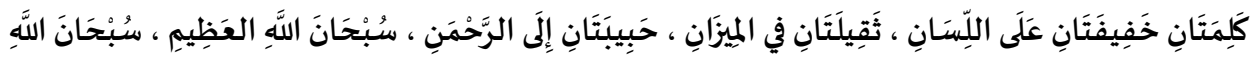

وَبْحَمْدِدِ

'Ada dua kalimat yang ringan di lidah, berat di timbangan, dicintai $A r$ Rabman (Allah), (yaitu) subbanallabi wa bihamdibi subhanallabil 'aşim'.

Selain itu dalil lain yang mebuktikan bahawa yang dimaksud dengan timbangan di sini adalah timbangan amal perbuatan di hari kiamat yakni bahwa di dalam kehidupan dunia ini tidak ada timbangan secara hakiki yang menimbang amal perbuatan manusia.

Maksud yang sebenarnya daripada hadis tersebut di atas adalah Rasulullah shallallahu 'alaibi wa sallam menjelaskan bahwa tidak ada perkara yang lebih berat dari akhlak yang terpuji pada almizan (timbangan) -di hari kiamat-. Pengekalan kata almizan dan penambahan keterangan di hari kiamat perlu

21 al-Bukhari, M. I., 1987. al-Jami' al-Musnad al-Shabih al-Mukhtashar Min Umuri Rasulillabi Shallallabu 'Alaihi wa Sallam wa Sunanibi wa Ayyamibi. Beirut: Dar Ibn Katsir, 1987. Hal. 1 • ₹/23. 
dilakukan agar para pembaca tidak lagi bertanya timbangan apa? Sebab hadis ini menjelaskan salah satu akidah dan keyakinan orang-orang yang beriman kepada Allah dan hari kiamat yaitu beriman dengan adanya timbangan amal perbuatan manusia.

Hal ini dapat diperjelas dengan firman Allah Ta'ala di dalam surat AlQari'ah ayat 6 dan 7:

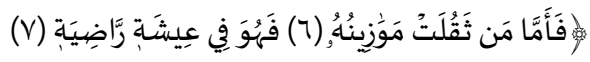

"Adapun orang yang berat timbangan amal baiknya, (6) Maka ia berada dalam kehidupan yang senang lenang (7)".

Oleh sebab itu, berdasarkan teori konteks situasi sebagaimana telah disebutkan sebelum ini maka terjemahan ini merupakan terjemahan salah.

\begin{tabular}{|c|c|c|}
\hline No. & Teks sumber & Teks sasaran \\
\hline 89 & 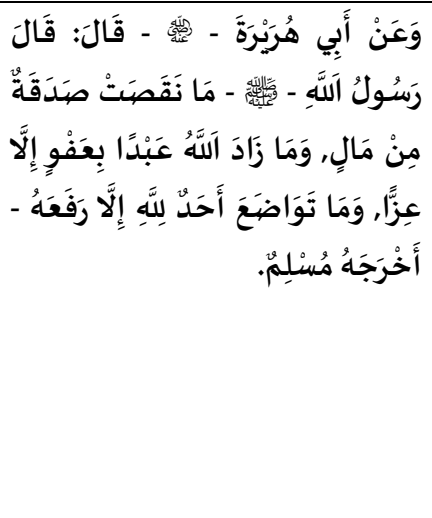 & $\begin{array}{l}\text { Dari Abu Hurairah, ra., ia berkata: } \\
\text { Bersabda Rasulullah saw.: "Tidak } \\
\text { berkurang sedikitpun harta yang } \\
\text { disedekahkan itu, dan hamba yang } \\
\text { senantiasa memohon tambahan ampunan } \\
\text { dari Allah dengan ke AgungaNya. Dan } \\
\text { tidak ada seorangpun yang berbuat baik } \\
\text { karena Allah (merendahkan hati karena } \\
\text { Allah), kecuali Allah akan } \\
\text { mengangkatnya". (Hadits dikeluarkan } \\
\text { oleh Imam Muslim). }\end{array}$ \\
\hline
\end{tabular}

Dalam kasus terjemahan hadis nomor 89 ini terjadi kesalahan dalam

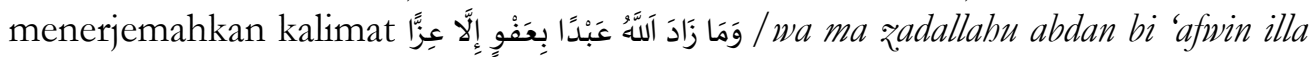
izzan/ yang diterjemahkan menjadi 'dan hamba yang senantiasa memohon tambahan ampunan dari Allah dengan ke AgungaNya'. Dalam teks terjemahan ini ada beberapa kesalahan yaitu:

1. Kesalahan dalam menentukan referen untuk perdikat زَاد leksikal berarti 'menambah' dan bukan 'memohon tambahan'. Sehingga terjemahan ini menjadi salah dalam menyampaikan pesan selain kalimatnya yang tidak sempurna. Kata (ja/zada/ di dalam hadis ini adalah fíl madhi yang secara leksikal berarti 'menambahkan' sedangkan fa'il atau subjek dari fi'l ini adalah lafaz jalalah (Allah). Artinya 'Allah menambahkan'.

2. Jumlah atau kalimat ini adalah kalimat manfiyah (didahului oleh barf nafyin $\mathrm{L} / \mathrm{ma} /$. Artinya perdikat yang datang setelah $\mathrm{L} / \mathrm{ma} /$ secara semantik

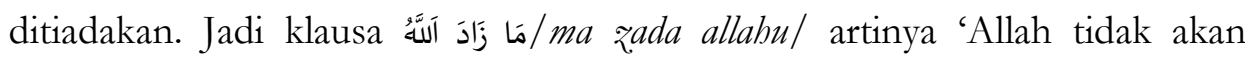
menambah'. Sedangkan di dalam teks sasaran kalimatnya jadi berubah menjadi hamba yang senantiasa memohon tambahan. 
3. Frasa بِ بِعَفِ /bi 'afwin/ di terjemahkan menjadi 'ampunan', di dalam teks sasaran kata ampunan memiliki fungsi sintaksis sebagai sebagai objek dari

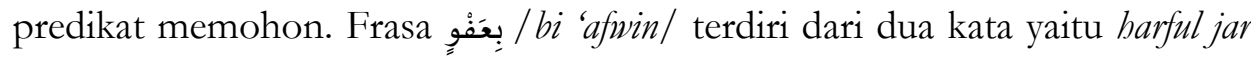

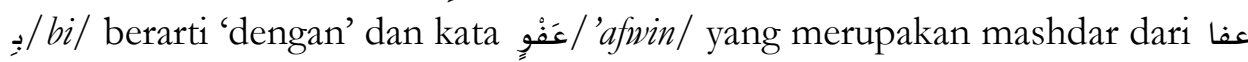
- /'afa - ya'fu/ berarti memaafkan.

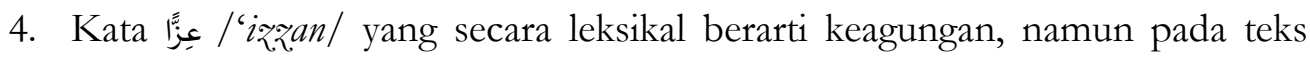
sasaran kesalahan terjadi saat kata teresbut disandarkan kepada pronominal (Nya) yang dipahami kembali kepada lafaz jalalah (Allah). Artinya pada teks sumber sebenarnya kata عِ ع $/$ 'iqzan/ itu tidak bersandar pada pronominal apapun, kata tersebut secara sintaktis memiliki fungsi sebagai maful bihi atau objek dari verba 1 / $/ 2$ ada/ sebagaimana telah disinggung di atas.

Maksud dari kalimat وَمَا زَادَ الَلَّهُ عَبْدًا بِعَفْوٍ إِلَّا عِنًا adalah bahwa Allah pasti akan menambah kemuliaan seseorang dengan sikap memaafkan orang yang telah berbuat buruk kepadanya. Jika ingin diterjemahkan secara literal bunyinya menjadi "tidaklah Allah menambah kepada seorang hamba dengan kemaafannya kecuali kemuliaan".

\section{Penutup}

Setelah melakukan serangkaian prosedur penelitian yang telah diuraikan pada bab-bab sebelumnya ditemukan kesalahan-kesalahan dalam terjemahan hadis-hadis Kitäbul Jämi' dari kitab Bulüghul Marām karya Moh. Machfuddin Aladip. Kesalahan-kesalahan tersebut terjadi karena beberapa faktor, yaitu. pemadanan yang tidak tepat secara leksikal, penambahan kata atau frasa melebihi kata pada teks sumber, pergeseran yang terjadi pada tataran kata, penghilangan padanan kata dan frasa, dan kesalahan mengidentifikasi kata di dalam bahasa sumber.

\section{Bibliografi}

Abdulqayyum, A., 1417. Mafhum Al-Mukbalafah Wa Attatbiq 'Alaibi Min Ahadis Al-Mu'amalat Min Kitab Bulīg Al-Maräm. Makkah: Ummul Qura.

Aladip, M. M., 2012. Terjemah Bulughul Maram. Semarang: PT. Karya Toha Putra.

Albassam, A. A., 2003. Taudhiul Abkam min Bulüghul Maräm. Makkah: Maktabah Al-Asdiy.

Al-Bukhari, M. I., 1987. Al-Jami' Al-Musnad Al-Shabih Al-Mukbtashar Min Umuri Rasulillabi Shallallabu 'Alaibi Wa Sallam Wa Sunanibi Wa Ayyamibi. Beirut: Dar Ibn Kathir.. 
Alkatabi, M. A., n.d. Basyir Al-Kiram BiBulüghul Marām. Surabaya : Bongkol Indah.

Alqadusi, A. H., 2010. Atsar Al-Qira At Al-Quraniyah Fi Al-Shina'ati AlMu'jamiyah Tajul 'Arus Namudrajan. Cairo: Helwan .

Al-Utsaimin, M. S., 2006. Fathu Dril Jalali wal Ikram Bi Syarbi Bulughil Maram. Cairo: Al-maktabah al-islamiyah.

Anon., 2008. Kamus Besar Bahasa Indonesia. Jakarta: Pusat Bahasa Departemen Pendidikan dan Kebudayaan.

As-Sa'diy, A. N., 1416H. Taisir Al-Karimi Al-Rahman Fi Tafsiri Kalamil Mannan. Al-Qasim-Buraidah: Dār Ashdā Al-Mujtama'.

As-Shan'ani, M. I., 2001. Subulussalām Al-mūshilatu ilā bulüghil marām. Riyad: Darul 'Ashimah.

Attahhan, M., 2010. Taisir Ilmi Mushthalabil Hadis. Riyad: Maktabah Al-Ma'arif Li Al-nasyri wa Al-Tauzi'.

Azzerekli, K., 2002. Al-A'lam. Beirut: Dar Al-'Ilmi Lil-Malayin..

Az-Zurqani, M. A. A., 1996. Manabil Al-'Irfan Fi 'Ulumi Al-qur'an. Riyad: Maktabah Nazar Mustafa Al-Baz.

Catford, J. C., 1965. Linguistic Theory of Translation: An Essay in Applied Linguistics. London: Oxford University.

Hanbal, A., 1999. Musnadul Imam Ahmad bin Hanbal. Beirut: Muassasaturrisalah.

Hoed, B. H., 2006. Penerjemahan dan Kebudayaan. Jakarta: Pustaka Jaya.

Hotib, M., 2006. Analisis Diksi Terjemahan Buku Bulüghul Maräm Pada Bab Riba Versi "A. Hasan". Jakarta: Universitas Islam Negeri Syarif Hidayatullah.

Ibrahim, dkk, Almu'jam Alwasith, Mesir: Maktabah Asysyuruq Addauliah, 2004.

Khallaf, A. W., 2009. Imu Ushul Al-Fiqh.. Cairo: Maktabah Al-Dakwah Syabab Al-Azhar.

Larson, M. L., 1989. Penerjemahan Berdasar Makna: Pedoman Untuk Pemadanan Antar Bahasa. (K. W. Taniran, Trans.). Jakarta: Arcan.

Lubis, M. H., 2009. Pengantar Ilmu Penerjemahan. Medan: Bartong Jaya.

Malik, A., 1985. Al-Muwatta. Beirut: Dar Ihya' Al-turas.

Mansoer, P., 1988. Linguistik Sebuah Pengantar. Gorontalo : Angkasa.

Manzur, M. M., 1414H. Lisan Al'arab. Beirut: Dar Sadir.

Moentaha, S., 2006. Bahasa dan Terjemahan. Jakarta: Kesaint Blanc.. 
Muhammad Zulfadli, Leni Kurni Herlia, Puji Lestari, Resty Anindita Fitriani, 2015. restyanindita.blogspot.com.

[Online]

Available at: (http://restyanindita.blogspot.com/2015/05/aliranlinguistik-aliran-konteks_94.html)

[Accessed 20 April 2020].

Munawwir, A. W., 2007. Kamus Al-Munawwir Arab-Indonesia Terlengkap. Surabaya: Pustaka Progressif. , n.d. Alquranul Karim. Depok: Sabiq.

Nida, E. A. \&. T. C. R., 1969. The Theory And Practice of Translation. Leiden: E.J Brill.

Nurdiansyah, L., 2008. Hal Dalam Babasa Arab Dan Padanannya Dalam Babasa Indonesia (Analisis Terbadap Buku Terjemahan Bulugh Al-Maram Oleh Drs. Machfudin Aladip Pada Bab Thabarah). Jakarta: Universitas Islam Negeri Syarif Hidayatullah.

Pinchuck, I., 1977. Scientific and Technical Translation.. London: Andre Deutsch.

Savory, T., 1969. The Art of Translation. London: Jonathan Cape.

Sudaryanto, 1993 . Metode dan Aneka Tehnik, Analisis Bahasa. Yogyakarta : Duta Wacana University Press.

Sunarto, A., 2006. Syarah Bulīghul Maräm. Surabaya: CV. Karya Utama..

Suryana, Y., 2015. Bulügbul Maräm Panduan Kesempurnaan Ibadah Seorang Muslim.. Bandung : PT. Cordoba Internasional Indonesia..

Yasir, M. S. H., 1428H. Mafhum Al 'Adad Wa Tațbiiqaätubu Min Kitäb Bulüg AlMaräm.. Makkah: Universitas Ummul Qura Saudi Arabia.

Zamri, 2014. Studi Analisis Balaghoh Tentang Istifham Dan Makna - Maknanya Dalam Kitab Bulughul Maram Min Adillah Al - Abkam Lil Hafiřb Ibnu Hajar Al-Asqalani. Riau: Universitas Islam Negeri Sultan Syarif Kasim. 